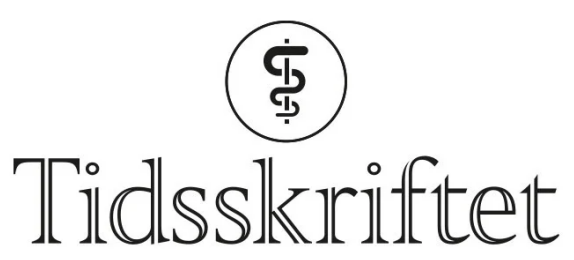

DEN NORSKE LEGEFORENING

\title{
Rettelse: Legionellose etter smitte fra fontenen på Youngstorget
}

RETTELSE

\section{TORE WFLGAARD STEEN}

tore.steen@bgr.oslo.kommune.no

Helseetaten

Oslo kommune

Tore Wælgaard Steen er dr.med., spesialist i allmennmedisin og i samfunnsmedisin og tidligere smittevernoverlege i Helseetaten. Han arbeider nå i bydel Grorud.

Forfatteren har fylt ut ICMJE-skjemaet og oppgir ingen interessekonflikter.

\section{ÅSE RUTH EGGEMOEN}

MARTE ANDERSEN

TOVE CHRISTIANSEN

FREDRIK EIKA

Medisinsk avdeling

Diakonhjemmet Sykehus

Fredrik Eika er lege i spesialisering i indremedisin.

Forfatteren har fylt ut ICMJE-skjemaet og oppgir ingen interessekonflikter.

INGUNN HAAKERUD

KNUT HENRIK SPAEREN

Tidsskr Nor Legeforen 2021; 141: 1085-6.

I Tidsskriftet nr. 11/2021, s. 1086 skal det stå: Vi har fått opplyst fra Stavanger universitetssjukehus at det er funnet genotype 256 hos én annen pasient fra Oslo med påvist legionellose i 2020.

Vi beklager feilen, den er rettet på nett.

Publisert: 2. september 2021. Tidsskr Nor Legeforen. DOI: 10.4045/tidsskr.21.0576 
(C) Tidsskrift for Den norske legeforening 2023. Lastet ned fra tidsskriftet.no 26. april 2023. 